\title{
A COMPARISON OF THE RESPONSES TO THREE COMPREHENSION AND THREE PRODUCTION TASKS ASSESSING THE MORPHO-SYNTACTIC ABILITIES OF AFRIKAANS-SPEAKING PRESCHOOLERS
}

Frenette Southwood

University of Stellenbosch

The lack of standardised assessment instruments for assessing the morpho-syntactic abilities of Afrikaans-speaking children often leads to the use of informal assessment tools and/or spontaneous language samples. The question that this paper addresses is how best to assess these morpho-syntactic abilities when using nonstandardised assessment instruments of this kind. The general aim of the present study was to answer this question. Eight typically developing, monolingual children (one boy and one girl of 3, 4, 5, and 6 years) from monolingual Afrikaans-speaking homes participated. Tasks were administered to assess comprehension and production of grammatical features related to number, person, case, and tense, as well as questions forms, binding relations and passive constructions. The comprehension tasks entailed picture selection, judging the (in)correctness of utterances produced by the researcher, and question answering, whereas the production tasks consisted of sentence completion, question asking and a language sample. A specific aim of the study was to determine which method(s) rendered the highest number of (i) correct responses and (ii) usable responses (i.e., responses strictly related to the aspect under assessment) by these typically developing participants. The results indicate that picture selection elicited the highest number of both correct and usable responses in the comprehension tasks. The production task that provided the highest number of both correct and usable responses was language sample elicitation. This suggests that these tasks should receive precedence when assessing the morpho-syntactic abilities of Afrikaans-speaking preschool children.

\section{INTRODUCTION}

There is no generally accepted protocol for the identification of children with language disorders in South Africa. Of the existing tests of receptive and expressive language abilities, very few have been standardized on Afrikaans-speaking children. ${ }^{1}$ Yet South African clinicians are routinely expected to make judgments on the normalcy of the expressive language abilities of these children as part of school-readiness testing. Consequently those who need to assess the expressive morpho-syntactic abilities of Afrikaans-speaking children have either to devise their own informal assessment tools or to make use of spontaneous language samples, not merely to monitor the progress of language intervention, but also to make diagnoses. 
This small-scale study forms a part of a larger project which aims to describe and explain some of the properties of specific language impairment as it presents in Afrikaans. One of the goals of this larger project is to construct tests to determine how the grammatical features person, number, case, and tense are comprehended and produced by three groups of Afrikaans-speaking children, namely typically developing and specific language impaired 6year-olds, and younger typically developing children who have the same mean length of utterance measured in morphemes (MLU) as the specific language impaired 6-year-olds. The aims of this small-scale study were, firstly, to gain normative data on the morpho-syntactic abilities of typically developing Afrikaans-speaking preschool children, and, secondly, to assess the appropriateness of the above-mentioned tests. This paper reports on the second of these two aims.

Four age groups were included in this small-scale study. The 6-year-olds were included to determine whether the cognitive demands placed on them by the test items and procedures are such that children of this age can perform the tasks with a high level of accuracy. The 4year-olds were included because this is the likely age of the one group of controls of the larger study (those matched with the 6-year-olds in the experimental group in terms of MLU). This prediction is based on the fact that other researchers (cf. Rice, 2003:72) found that the MLU-matched controls were on average 2 years younger than the experimental group consisting of children with specific language impairment (in Rice's case, the children with specific language impairment were 5-year-olds). The purpose of testing these 4-year-olds was two-fold: firstly, to determine whether the vocabulary used is known to this age group and whether the visual material and instructions used is clear to them; and, secondly, to determine whether the test items result in different performance between these children and the typically developing 6-year-olds. This was important because the performance of the 6-year-old children with specific language impairment is to be compared to that of both the typically developing 6-year-olds and typically developing younger children in the larger study. Obviously, if the results for the two groups are similar, then the comparisons planned for the larger study would not make sense (given that the same test items are to be used in the larger study as in this small-scale study). Two other age groups, namely 3-year-olds and 5-yearolds, were also included in this small-scale study. There were two reasons for including these two groups. Firstly, the predictions of the probable age of the MLU-matched controls could be inaccurate, in which case there would be data on how children younger and older than 4 years fared on the test items and procedures. Secondly, there is a lack of developmental data for Afrikaans. The inclusion of these two groups created the possibility of collecting potentially valuable preliminary cross-sectional data on the development of the comprehension and production of grammatical morphemes by young Afrikaans-speaking children.

The reason for focusing on morpho-syntactic abilities (and not on, for example, vocabulary size or pragmatic skills) is that, despite their heterogeneity, there is one property that is shared by most children with specific language impairment, namely that they are especially weak in their use of grammatical morphemes (e.g., Gopnik, 1990; Leonard, Bortolini, Caselli, McGregor \& Sabbadini, 1992; Ullman \& Gopnik, 1994) and also in their ability to move sentence constituents appropriately (Leonard, 1995; Van der Lely, 1996).

There is extensive crosslinguistic data on weakness in the use of grammatical morphemes in children with specific language impairment, for instance in Dutch (De Jong, 2004); German (Clahsen, 1988, 1989; Clahsen \& Rothweiler, 1992; Lindner \& Johnston, 1992); Swedish 
(Håkansson, 1998; Hansson \& Nettelbladt, 1995; Leonard, Salameh \& Hansson, 2001); French (Paradis \& Crago, 2000; Rose \& Royle, 1999); Italian (Bortolini, Caselli, Deevy \& Leonard, 2002; Bortolini, Leonard \& Caselli, 1998; Leonard, Sabbadini, Volterra \& Leonard, 1988); Greek (Dalalakis, 1994, 1997; Stavrakaki, 2001, 2002; Tsimpli \& Stavrakaki, 1999); Hebrew (Rom \& Leonard, 1990); Japanese (Fuduka \& Fuduka, 1994; Tanaka Welty, Wanabe \& Menn 2002); and Zulu (Demuth \& Suzman, 1997; Suzman, 2002). However, Afrikaans differs from the other languages in which specific language impairment has been studied thus far: in Afrikaans, very few grammatical features are realised phonetically. At the same time, Afrikaans shows more word order variation than does, for example, English. The question which arises is: If children with specific language impairment experience problems realising grammatical features correctly, how does specific language impairment present in Afrikaans, a language in which grammatical features are realised phonetically in a very limited way even by adult speakers, but where there is frequent overt movement assumed in minimalist syntax to be driven by the need to check features (e.g., Hornstein, Nunes \& Grohmann, 2003)? In order to answer this question, one first needs to determine what the morpho-syntactic abilities of typically developing Afrikaans-speaking children are. This small-scale study intended to investigate how one can best determine what these abilities are.

A comparison was made between the results rendered by various types of comprehension tasks, and between the results rendered by three production tasks of which one was language sample analysis. The aims were to determine (i) whether different types of tasks rendered comparable scores for each of the even aspects assessed, and, if not, which of the tasks rendered the highest scores, and (ii) which type of task rendered the most usable responses.

\section{METHODOLOGY}

\section{Participants}

Eight children (four groups of two one boy and one girl from each of the following age groups) participated in the small-scale study: 3, 4, 5, and 6 years old. All participants were monolingual speakers of Afrikaans from monolingual Afrikaans-speaking homes. According to their parents and classroom teachers, all participants demonstrated age-appropriate development related to language, socio-emotional aspects, and intellect; all had normal hearing sensitivity, according to their parents (and confirmed by a hearing screening test) and no significant history of middle-ear infections; none showed evidence of any visible neurological deficits; and no participant had previous referrals to or treatment by a speechlanguage therapist.

\section{Framework of procedures}

Possible participants where identified by contacting a child care facility in Stellenbosch and asking the classroom teachers to identify every 3-, 4-, 5-, and 6-year-old who met the selection criteria. The parents of all these children were sent an information letter, a questionnaire on biographical and developmental information, and a parental consent form. From those children whose parents completed and returned the questionnaires and consent forms, and who met the selection criteria according to their parents, the eight participants were selected randomly. Arrangements were made for the researcher to visit each participant 4 to 6 times at the child care facility. During these visits, a child assent form was completed 
with the child, a hearing screening test was performed, language assessment tasks were administered, and a spontaneous language sample was gathered.

\section{Data collection}

All data collection was done by the researcher. Background information on (amongst other things) the participants' language, speech, and hearing development was collected via a questionnaire, filled out by their parents.

During the performance of the language assessment tasks, which are described in the next section, the researcher and participant sat next to one another on lounge chairs in a quiet room at the child care centre. During language sample elicitation (also described in the next section), the researcher and participant played alone in the same room. Participants could rest at any stage during the language assessment session, and could also request any particular visit to end.

\section{Language assessment tasks and material}

The procedures used to test the participants' comprehension and production of grammatical morphemes have been used successfully with typically developing and specific language impaired young children of different languages by various researchers (e.g., Gualmini \& Crain, 2002; Gualmini, Crain \& Meroni, 2000; Håkansson, 2001; Hansson \& Leonard, 2003; Jakubowicz, 2003; Marchman, Saccuman \& Wulfeck, 2004; and Ravid, Levie \& Avivi BenZvi, 2003). An example of each kind of task is given in the Appendix A.

\section{Comprehension tasks}

The general format for the tasks assessing the comprehension of grammatical features was the same, regardless of the grammatical feature being assessed. Three types of tasks were used. The first was picture selection. In this type of task, the researcher showed the participant a sheet with more than one picture and asked the participant to select the one that matches the researcher's utterance. The following were assessed in this way (the number of items included in each subtask is provided in parentheses):

- For number comprehension (40) -

- Singular forms of real words (20)

- Regular plural forms of real words, such as ketels 'kettles' or katte 'cats' (10 each for $-s$ and $-e=20$ )

- For person and case comprehension, on pronouns (32)

- For comprehension of genitive case, using se-constructions, as in die meisie se bal 'the girl's ball' (5)

- For tense comprehension (24) -

○ Main verbs which take the ge-prefix in the past participle form, such as klim 'climb' or (het) geswem 'swam' (12)

- Main verbs which do not take the $g e$ - prefix in the past participle form, such as (het) betaal 'paid' (2)

○ To be forms (4)

- To have forms (2)

○ Modal auxiliaries, as in moes gaan 'had to go' (4)

- For comprehension of binding forms, such as Die honde jaag mekaar 'The dogs are chasing each other' (5) 
- For comprehension of passive constructions, such as Die vis word deur die padda gegooi 'The fish is thrown by the frog' (10)

The second type of comprehension task was a judgement task. The researcher described a picture and the participant had to judge whether utterances produced by the researcher were acceptable in Afrikaans, i.e., the participant had to tell the researcher when she made a mistake. The following were assessed in this way (again, the number of items included in each subtask is provided in parentheses):

- For number comprehension (94)-

- Regular plural forms of real words, such as *tandes 'teeth' (2 each for $-s$ and $-e$ used correctly; 4 each for $-s$ and $-e$ used incorrectly)

- Irregular plural forms of real words, such as *golfe 'waves' (17 used correctly; 16 incorrectly)

- Regular plural forms of nonsense words, such as kottels or sane (12 for $-s 10$ for $-e$ used correctly; 15 for $-s$ and 8 for $-e$ used incorrectly)

- Irregular plural forms of nonsense words, such as *liffe (2 used correctly; 2 incorrectly)

- For person and case comprehension, on pronouns (32)

- For comprehension of genitive case, using se-constructions, as in *die man koerant 'the man newspaper' (5 used correctly; 5 incorrectly)

- For tense comprehension -

○ Hendiadys, such as lê en lees 'reading while lying down' (5 used correctly; 5 incorrectly)

- For comprehension of binding forms, such as Die kat jaag homself 'The cat is chasing himself' to describe a picture of a cat chasing a mouse ( 2 used correctly; 3 incorrectly)

The third type of comprehension task involved answering questions. This was only used for the assessment of question forms. In total, 18 question forms were assessed.

\section{Production tasks}

As was the case for the comprehension tasks, the general format for the tasks assessing the production of grammatical features was the same, regardless of the grammatical feature being assessed. Two types of tasks were used. The first was sentence completion. In this type of task, the researcher and participant looked at a picture, the researcher initiated a sentence, and the participant had to complete that sentence. The following were assessed in this way (the number of items included in each subtask is provided in parentheses):

- For number production (98) -

- Regular plural forms of real words, such as mandjies 'baskets' or geboue 'buildings' (10 each for $-s$ and $-e$ )

- Irregular plural forms of real words, such as gebede 'prayers' (30)

- Regular plural forms of nonsense words, such as fienders or gesse (24 for $-s$ and 20 for $-e$ )

- Irregular plural forms of nonsense words, such as lerge (4)

- For person and case production, on pronouns (64)

- For production of genitive case, using se-constructions, as in die gogga se poot 'the bug's leg' (10)

- For tense production (18) -

- Main verbs which take the ge-prefix in the past participle form, such as (het) gedra 'wore' (4) 
- Main verbs which do not take the ge-prefix in the past participle form, such as (het) ontvang 'received' (2)

○ To be forms (2)

- To have forms (2)

- Modal auxiliaries, as in wou swem 'wanted to swim' (6)

○ Hendiadys, as in gesit en slaap 'slept while sitting' (2)

- For production of binding forms, such as Die meisie sien haarself in die spieël 'The girl sees herself in the mirror' (15)

- For production of passive constructions, such as Die pizza word deur die leeu geёet 'The pizza is being eaten by the lion' (10)

The second type of production, used only used for the assessment of question forms, entailed asking questions. The production of simple wh-questions was assessed by showing the participant a picture in which some information was missing. The participant needed to ask the 'right' question before the missing information was revealed. The production of paired wh-questions was assessed using a similar procedure to the one used to elicit simple whquestions. In this case, however, the question had to contain two wh-words in order to be 'right'.

Each comprehension and production task had two practice items, in order to familiarise the participants with the tasks and with what was required of them.

\section{Language sampling}

Language sample elicitation took the form of freeplay with toys that included (i) tiny dolls with accessories such as radios, hats, mugs, and brooms; (ii) wooden building blocks; and (iii) plastic building blocks and kitchen furniture. The researcher initiated the language sampling interaction by inviting the participant to join in building a house and assembling the kitchen. The rest of the session proceeded according to the guidelines provided by Crystal, Fletcher, and Garman (1989: 213): The researcher played alone with the participant in a manner that she viewed to be appropriate and natural. If the participant was quiet for extended periods, the researcher prompted him/her with questions such as "What will happen next?" or "What are you doing?"

In the literature, there is no consensus as to the preferred number of utterances in a language sample, but Crystal, Fletcher, and Garman (1976: 87) suggested that a 30-minute interaction, usually yielding 100 to 200 utterances, would suffice. However, Southwood and Russell (2004:369) found that 15 minutes of freeplay elicited an average of 144 utterances from Afrikaans-speaking 5-year-olds, and, therefore, the language samples collected in this study were each 15 minutes long.

\section{Data transcription and scoring}

All responses on the comprehension and production tasks were recorded on a score sheet. Self corrections were allowed, and the final response was the one scored. (Final) responses were placed into one of the following three categories: (i) correct response, (ii) unusable response, such as word substitutions when assessing the production of plural morphemes (e.g., the researcher saying Een ghoen, twee ... 'One marble, two ...' and the participant responding with ysterballetjies 'little iron balls', or Ek weet nie 'I don't know'); and (iii) 
incorrect response. Incorrect responses were further divided into (i) those giving insight into the aspect being assessed (for instance, the participant pointing to visse 'fish-PLURAL' when asked to select the picture matching vis 'fish-SINGULAR'), and (ii) those not offering insight into the specific aspect being assessed (e.g., the participant pointing to kis 'coffin' or voël 'bird' when asked to select the picture matching vis 'fish-SINGULAR'). The latter, (ii), would reveal something about the test instrument rather than the participant's comprehension of number.

The first 100 utterances occurring in the 15 minute-long language sample of every participant were transcribed orthographically, excluding exact utterance repetitions but including utterances containing unintelligible segments. Following Brown (1973: 54), fillers such as $m m$ or $o$ 'oh' were ignored, whereas ja 'yes'/'yeah', nee 'no' and greetings were included. The presence of the following was tallied: (i) the number of correct grammatical morphemes related to tense, number, person, and case; (ii) the number of incorrectly used grammatical morphemes related to tense, number, person, and case; (iii) the number of omissions of these morphemes from obligatory contexts; (iv) the number of correct wh-question forms, utterances involving binding, and passive constructions; and (v) the number of incorrect whquestion forms, utterances involving binding, and passive constructions. Due to the limited number of participants, results were not analysed statistically.

As only typically developing children participated in this small-scale study, no response or utterance was seen to be pathological or indicative of abnormal language behaviour. Rather, so-called errors were regarded as indicative of a still developing morpho-syntactic system of participants.

\section{RESULTS AND DISCUSSION}

The results are presented in table format (with the exception of tense production). Results are mostly given in the form of an average for all eight participants. Scores are given in the form of percentages (with the exception of question production), followed in brackets by a raw score. Where results for the various age groups are given separately, it will be noticed that the possible maximum score for any one assessed aspect differs among the participants. This is because the following were excluded from the count of each individual participant: items to which a response such as Ek ken nie daardie woord nie 'I do not know that word' was given; and responses which entailed certain substitutions, such as stouterds 'naughty ones' to the item Hier is een dief en hier is 'n klomp ... 'Here is one thief and here are many ...'. Items which rendered unusable responses are presented and briefly discussed in Appendix B.

\section{Comprehension tasks}

The first comparison is between the scores obtained by the participants on the three types of comprehension tasks. To calculate these scores, unusable response and incorrect responses not offering insight into the specific aspect being assessed were not tallied. In other words, only responses offering insight into the participants' comprehension of the seven aspects were considered when calculating these scores. As can be seen in Table 1, four of the seven aspects were assessed in two ways. 


\begin{tabular}{|l|c|c|c|}
\hline \multicolumn{1}{|c|}{ Tasks } & Picture selection & Judgement & $\begin{array}{c}\text { Question } \\
\text { answering }\end{array}$ \\
\hline Number comp & $68 \%(205 / 300)$ & $60 \%(447 / 745)$ & --- \\
Person and case comp & $81 \%(207 / 256)$ & $79 \%(201 / 253)$ & --- \\
Genitive case comp & $88 \%(35 / 40)$ & $73 \%(58 / 79)$ & --- \\
Tense comp & $60 \%(115 / 191)$ & $60 \%(44 / 73)$ & --- \\
Binding comp & $75 \%(24 / 32)$ & $76 \%(34 / 45)$ & --- \\
Passive comp & $31 \%(25 / 80)$ & --- & --- \\
Question comp & --- & --- & $62 \%(89 / 144)$ \\
\hline Total: Average score of all age & & & \\
groups on all aspects combined & $68 \%(755 / 1116)$ & $65 \%(750 / 1150)$ & $62 \%(89 / 144)$ \\
\hline
\end{tabular}

Table 1: Scores obtained on comprehension tasks

For three of these aspects, namely person and case comprehension, tense comprehension, and binding comprehension, the scores obtained by performing the picture selection and the judgement task were highly comparable. For number comprehension and genitive case comprehension, participants (as a group) fared better on the picture selection task. A possible explanation for this is that the judgement tasks required more metalinguistic skills than did the picture selection tasks and were therefore more difficult for the participants to perform accurately.

The next comparison of comprehension tasks is also given in the form of participants' responses, but here all usable responses (i.e., both correct as well as those incorrect responses offering insight into the aspect being assessed) were tallied. If a participant, for instance, selected a picture of a bus towing a car in response to the researcher saying die bus word deur die kar gesleep 'the bus is towed by the car', this response was included, because it shows that the child does not understand which entity is performing the action concerned. However, if the participant selected the picture of a bus towing a bicycle, the response was not included in the scores given in Table 2, seeing that such a response does not (necessarily) shed any light on whether or not the child understands this particular passive construction.

\begin{tabular}{|l|c|c|c|}
\hline \multicolumn{1}{|c|}{ Comprehension tasks } & Picture selection & Judgement & $\begin{array}{c}\text { Question } \\
\text { answering }\end{array}$ \\
\hline Number & $89 \%(286 / 320)$ & $98 \%(751 / 768)$ & --- \\
Person and case & $100 \%(256 / 256)$ & $99 \%(253 / 256)$ & --- \\
Genitive case & $100 \%(40 / 40)$ & $96 \%(77 / 80)$ & --- \\
Tense & $62 \%(120 / 192)$ & $91 \%(73 / 80)$ & --- \\
Binding & $100 \%(32 / 32)$ & $90 \%(43 / 48)$ & --- \\
Passives & $100 \%(80 / 80)$ & --- & --- \\
Questions & --- & -- & $93 \%(134 / 144)$ \\
\hline Total: Average score of all age & \multicolumn{2}{|c|}{} \\
groups on all aspects combined & $88 \%(814 / 920)$ & $99 \%(1217 / 1232)$ & $93 \%(134 / 144)$ \\
\hline
\end{tabular}

Table 2: Scores of usable responses obtained on comprehension tasks

The number picture selection task contained several items unfamiliar to some participants, with the judgement task rendering more usable responses than the picture selection one. The two person and case comprehension tasks both rendered a very high number of usable 
responses. The genitive case picture selection task rendered only usable responses, but not so the judgement task.

For tense comprehension, the picture selection task itself proved problematic. The participant had to choose between three pictures: (i) one in which an action is being performed, (ii) one in which the action will still be performed, and (iii) one in which the action has been performed. When the researcher used a past tense construction, however, participants often chose the picture in which the action is being performed instead of the one in which action has been performed. For instance, when shown a picture of an apple hanging on a tree, one of the same apple in mid-air, and one where the apple is already on the ground and told Wys vir my 'Die appel het geval' 'Show me 'The apple has fallen', participants often pointed to the picture in which the apple is still falling. While this was not the response targeted by the researcher, it cannot be classified as being incorrect, because (i) the picture demonstrates the action (falling) mentioned by the researcher, whereas the picture on the ground does not, and (ii) children's books are often written in the past tense form but illustrated with pictures showing the actions described in the text still being performed. One possible solution to this problem would be to show participants the three pictures and tell them that they have to listen carefully to two sentences produced by the researcher, and that the researcher will then tell them what to show her. For instance, for the falling apple item, the researcher could say, Luister mooi! Die appel het geval. Die appel val. Wys nou vir my 'Die appel het geval' 'Listen carefully! The apple has fallen. The apple is falling. Now show me 'The apple has fallen'.'

The tense judgement task also rendered unusable responses. These responses entailed comments by the participants on the social acceptability of what was said by the researcher instead of grammaticality judgements.

Regarding the assessment of binding relations, the picture selection task rendered only usable responses. However, on the judgement task there were similar responses to those to the tense judgement task above, i.e., social judgements were made by the participants.

It should be noted that although the current tasks assessing binding relations are not fully unproblematic, binding relations were initially assessed with a task which differs greatly from the one described here, one which yielded uninterpretable results. This initial task will be discussed briefly, in order to demonstrate the problems encountered when assessing comprehension of this aspect in the language of young Afrikaans-speaking children: A procedure similar to that of Franks and Connell (1996) were used. The participants listened to a tape-recorded story, while paging through a picture book of the same story, about a juice party. In the story, three characters (a bear, a lion, and a sheep) take turns to fill three glasses. When one character fills the glasses, another asks him who he is pouring the juice for. For example, Bear pours juice into a glass and Lion asks, Het jy daardie sap vir jouself ingeskink? 'Did you pour that juice for yourself?' Bear then answers, Nee, ek het hierdie sap vir Skaap geskink. 'No, I poured this juice for Sheep'. The first time the story was played, it was done non-stop without any comments from the researcher. During the second and third story sessions, the researcher stopped the tape after every episode, and said, Jammer, ek het nie nou geluister nie 'Sorry, I wasn't listening just now' and then asked the participant some questions about the episode. A small proportion of the questions asked were aimed at familiarising the participant with the task (e.g., Het Leeu die sap geskink? 'Did Lion pour the juice?), but the majority of the questions attempted to assess the participant's comprehension 
of binding relations (e.g., Het Leeu vir Beer gevra of hy sap vir hom ingeskink het? 'Did Lion ask Bear whether he poured juice for him?' or Het Beer vir Leeu gesê dat hy volgende vir homself sap sal inskink? 'Did Bear tell Lion that he would pour juice for himself next?'). Following Frank and Connell (1996: 445), who found that most of their participants with specific language impairment gave consistent responses in the first two presentations of the task, all the participants were allowed to respond to same set of questions twice, in order to compensate for the fact that the task was demanding. This task was one which participants enjoyed to such an extent that they often asked to do it again during later visits. Due to the ambiguity of some Afrikaans sentences containing binding relations, however, the results obtained from this task was not usable. For example, in the question mentioned above, Het Leeu vir Beer gevra of hy sap vir hom ingeskink het?, the hom could refer to any of the three characters in the story, so it did not matter what the participants' answer was; without the participants explaining to the researcher why they answered in a certain way, the researcher had no way of knowing whether or not they had comprehended the binding relation in this question. For this reason, the task was discarded and replaced by the picture selection task, where execution was unproblematic and the results obtained were interpretable.

No judgement task was employed to assess comprehension of passive constructions. Although several participants selected pictures matching an utterance in the active voice in the picture selection task, there was only one unusable response, i.e., one response which did not shed light on whether or not the participant understood the researcher's utterance.

From the above, it is clear that one problem with the judgement tasks as a whole is that is it not apparent why the participant decided that a certain item was correct or incorrect. For example, some children, when asked to judge Een sokkie, *baie sokkiese 'One sock, many socks', simply said Verkeerd 'Wrong'. This could lead the researcher to assume that they knew the plural form of the word sokkie. However, other children said Verkeerd, dis kouse 'Wrong, it's socks/stockings', which indicates that children may use criteria other those anticipated by the researcher to decide how to respond. The judgement task also at times yielded unexpected responses from the participants, who seemingly viewed what the researcher described as socially unacceptable. For instance, when showed a picture of a boy hiding in a dustbin and hearing Die seuntjie steek homself weg 'The boy is hiding', one participant said that the utterance is incorrect, want dan gaan sy ma en pa hom soek 'because then his mom and dad would go looking for him'. According to J. de Villiers (personal communication, February 2005), these responses are not necessarily an indication that the participants did not understand the task. It could also be that they understood the task, genuinely thought that the utterances were incorrect, but did not know how to explain what was wrong with the utterances (even though they were not under any obligation to give such explanations). When they are asked to exhibit metalinguistic skills which they do not yet possess, these children offer alternative explanations for their judgements.

Two of the age groups fared worse on the picture selection task assessing comprehension of binding relations than they did on the sentence completion tasks assessing the production of binding relations, as shown in Table 3. Although there is no clear explanation for this finding, the same was found by De Villiers (2005) for children aged 4 years 6 months to 7 years 2 months, for binding relations. A similar pattern was observed for the assessment of genitive case: the picture selection and judgement tasks yielded worse results than did the sentence completion task assessing the production of genitive case. Again, no clear explanation can be offered for this phenomenon. 


\begin{tabular}{|l|c|c|c|}
\hline \multicolumn{1}{|c|}{ Tasks } & \multicolumn{2}{|c|}{ Comprehension } & $\begin{array}{c}\text { Sentence } \\
\text { Completion }\end{array}$ \\
\cline { 2 - 3 } & Picture selection & Judgement & \\
\hline Genitive case & $60 \%(6 / 10)$ & $70 \%(14 / 20)$ & $100 \%(20 / 20)$ \\
Average 3 yrs & $100 \%(10 / 10)$ & $58 \%(11 / 19)$ & $100 \%(20 / 20)$ \\
Average 4 yrs & $100 \%(10 / 10)$ & $65 \%(13 / 20)$ & $100 \%(20 / 20)$ \\
Average 5 yrs & $90 \%(9 / 10)$ & $100 \%(20 / 20)$ & $100 \%(20 / 20)$ \\
Average 6 yrs & $88 \%(35 / 40)$ & $73 \%(58 / 79)$ & $100 \%(80 / 80)$ \\
Average all years & & & \\
Binding & $52 \%(12 / 23)$ & --- & $65 \%(13 / 20)$ \\
Average 3 yrs & $73 \%(19 / 26)$ & --- & $80 \%(16 / 20)$ \\
Average 4 yrs & $83 \%(24 / 29)$ & --- & $76 \%(13 / 17)$ \\
Average 5 yrs & $89 \%(24 / 27)$ & --- & $84 \%(16 / 19)$ \\
Average 6 yrs & $75 \%(79 / 105)$ & --- & $76 \%(58 / 76)$ \\
Average all years & & & \\
\hline
\end{tabular}

Table 3: Correct responses on the genitive case comprehension and production tasks

For the third type of comprehension task, namely question answering, there was only one item which once yielded an uninterpretable response.

In summary, the picture selection elicited rendered the highest number of both correct and usable responses in the comprehension tasks. However, there were items even in this task which did not elicit a response indicative of whether or not the participant understood the aspect being assessed. This was even more so the case for the judgement and question answering tasks. However, it is unlikely that this problem of unusable responses can be overcome, given the nature of these responses to carefully selected items.

\section{Production tasks}

The first comparison between the three production tasks was on the scores each of them rendered. As can be seen in Table 4, more of the spontaneous productions (in the language sample) were correct than were the elicited productions (in the sentence completion and question asking tasks). The language sample elicited higher scores in response to question asking tasks. It should be noted, though, that no paired wh-questions appeared in the language sample. This type of question proved to be very difficult for all eight participants, which is one of the reasons for their low score on this task. Comparing the results of the question asking task and the language sample in terms of number of correct questions produced is, therefore, not useful. Also, the sentence completion tasks were designed to elicit a very wide range of utterances (for instance, the tense sentence completion task assessed hendiadys and the use of het with infinitives), whereas in the language sample the participants were able to choose which utterances they used (for example, no hendiadys nor any uses of het with infinitives occurred in the language sample of any of the participants). 


\begin{tabular}{|l|c|c|c|}
\hline \multicolumn{1}{|c|}{ Production tasks } & $\begin{array}{c}\text { Sentence } \\
\text { completion }\end{array}$ & $\begin{array}{c}\text { Question } \\
\text { asking }\end{array}$ & $\begin{array}{c}\text { Language } \\
\text { sample }\end{array}$ \\
\hline Number & $36 \%(267 / 739)$ & --- & $99 \%(464 / 468)$ \\
Person and case & $86 \%(376 / 436)$ & --- & $99 \%(576 / 579)$ \\
Genitive case & $100 \%(80 / 80)$ & --- & $100 \%(15 / 15)$ \\
Tense & $73 \%(89 / 122)$ & --- & $99 \%(535 / 537)$ \\
Binding & $76 \%(58 / 76)$ & --- & $100 \%(4 / 4)$ \\
Passives & $13 \%(10 / 79)$ & --- & $75 \%(3 / 4)$ \\
Questions & --- & $41 \%(33 / 80)$ & $99 \%(37 / 38)$ \\
\hline Total: Average score of all age & $52 \%$ & $41 \%$ & $99 \%$ \\
groups on all aspects combined & $(808 / 1554)$ & $(33 / 80)$ & $(1634 / 1645)$ \\
\hline
\end{tabular}

Table 4: Scores obtained on production tasks

As was done for the comprehension tasks, the next comparison is also given in the form of participants' responses, but in terms of number of usable responses, not in terms of number of correct responses. Table 5 shows the number of responses that the researcher could use to determine whether or not the participants could produce the seven aspects concerned.

With regard to number sentence completion, only three of the 50 real words used as test items were not known to at least 2 of the 8 participants. The unusable plural forms of nonsense words mostly entailed sound changes of such a nature that it did not reveal to the researcher whether the participant knew what the plural form of the word would have been, had the word actually existed in Afrikaans.

\begin{tabular}{|l|c|c|c|}
\hline \multicolumn{1}{|c|}{ Production tasks } & $\begin{array}{c}\text { Sentence } \\
\text { completion }\end{array}$ & Question asking & $\begin{array}{c}\text { Language } \\
\text { sample }\end{array}$ \\
\hline Number & $94 \%(738 / 784)$ & --- & $100 \%(468 / 468)$ \\
Person and case & $83 \%(423 / 512)$ & --- & $100 \%(579 / 579)$ \\
Genitive case & $100 \%(80 / 80)$ & --- & $100 \%(15 / 15)$ \\
Tense & $18 \%(26 / 144)$ & --- & $100 \%(537 / 537)$ \\
Binding & $88 \%(106 / 120)$ & --- & $100 \%(4 / 4)$ \\
Passives & $38 \%(30 / 80)$ & --- & $100 \%(4 / 4)$ \\
Questions & --- & $28 \%(22 / 80)$ & $100 \%(38 / 38)$ \\
\hline Total: Average score of all age & $82 \%$ & $28 \%$ & $100 \%$ \\
groups on all aspects combined & $(1403 / 1720)$ & $(22 / 80)$ & $(1645 / 1645)$ \\
\hline
\end{tabular}

Table 5: Scores of usable responses obtained on production tasks

For the sentence completion task evaluating the production of person and case (on pronouns), there were three main types of unusable responses. The first entailed the substitution of pronouns by nouns, and the second the use of ek en jy 'you and me' instead of ons 'we/us' or jy en $X$ 'you and $\mathrm{X}$ ' instead of julle 'you-PLURAL' (or similar). The third type of unusable response included the substitution of dit 'it' with hy 'he' or hom 'him'. Whereas such substitution is acceptable in Afrikaans, it does not reveal whether the participant knows how to realise person and case correctly on the third person singular pronoun dit.

The genitive case picture sentence completion task elicited only usable responses. Substitution of nouns did occur (as in die piesang se kop 'the banana's head' instead of the expected die seun se piesang 'the boy's banana' to Hier is die meisie se appel en hier is ... 
'Here is the girl's apple and here is ...'), but participant utterances containing such substitutions were taken to be correct and usable, seeing that they still gave the researcher information on whether or not the participant could use the se-construction correctly.

As was the case for the tense comprehension tasks, the tense production task also rendered a high number of unusable responses. There were two reasons for this. The first was that verb substitutions often occurred. For instance, when assessing the past tense production of a sentence containing a modal auxiliary (such as wou swem or wou geswem het 'wanted to swim'), the researcher could say, Hierdie eendjie wil elke dag swem. Gister net soos elke ander dag ... 'This duckling wants to swim every day. Yesterday, just like every other day, ...', to which the participant could say swem die eendjie 'the duck swam', which would be a correct response, but not one contained a modal auxiliary, let alone the targeted one. Secondly, in Afrikaans, it is acceptable to use the so-called historic present tense (a form of the verb which resembles the present tense and also the infinitive form) where past tense is denoted by, amongst others, the adverbial phrase. An acceptable option for the sentence Gister het ons koffie gedrink 'Yesterday we drank coffee' is Gister drink ons koffie, since past time is indicated by the adverb gister 'yesterday'. Therefore, when the researcher provided a stimulus such as Hierdie vrou pluk elke dag 'n blom. Gister, net soos elke ander dag, ... 'This women picks a flower every day. Yesterday, just like every other day, ...', a participant could respond in grammatical Afrikaans without using a past tense form of the verb. If the researcher wanted to elicit the past tense form after a historic present tense form was produced by the participant, the aspectual auxiliary het had to be provided by the researcher. Although this usually resulted in the past participle form of the verb then being used by the participant, it was not clear whether or not the response demonstrated the ability to produce the grammatical morphology associated with the grammatical feature tense, seeing that the word het, which carries the feature [+past], was provided to the participant. Therefore, such responses on the past tense production task were unusable.

The only unusable responses on the sentence completion task assessing binding relations were those where pronouns were substituted by a noun phrase.

The passive construction sentence completion task rendered a high number of unusable responses. Participants often responded in the active voice. To elicit the passive form where a construction in the active voice was produced by the participant, the researcher had to provide the cue word. In $35 \%(16 / 46)$ of the cases in which the researcher provided the participant with word, the participant produced a passive construction (albeit a short one, i.e., a passive construction without the prepositional by phrase, as in Die perd word gejaag "The horse is being chased' instead of Die perd word deur die seun gejaag 'The horse is being chased by the boy'). However, this response was no longer interpretable, as the cue word provided by the researcher forms part of what the researcher wanted to ascertain the participant could produce.

The second type of production task, namely question asking, rendered three types of unusable responses, namely guesses; no responses, even after the researcher repeated the stimulus; and the use of an unexpected question word. Where no response was given or the unexpected question word was used, the researcher provided the correct question word as a prompt. When participants then produced a question form, it was no longer clear how to interpret the child's production, seeing that the researcher had provided the word containing the whfeature. 
The third type of production task, namely language sample elicitation, rendered only usable responses. However, it gave information on a far more limited range of utterances.

Of the three production tasks, language sample elicitation rendered both the highest number of correct and usable responses. As was the case for the three comprehension tasks, however, unusable responses are seen as problematic, but it is not clear how this problem can be overcome, given the nature of the unusable responses and the lack of suitable alternative assessment tasks.

\section{CONCLUSION}

This small-scale study formed part of a larger project investigating the characteristics of specific language impairment as it presents in Afrikaans. In order to determine whether Afrikaans-speaking children with specific language impairment, like those of other languages, have more problems than typically developing children with grammatical morphology and constituent movement, one needs to compare the language abilities of these children with specific language impairment with those of their typically developing peers. In order to accomplish this, one needs to employ informal assessment tasks and/or make use of a language sample, given the lack of standardised language assessment instruments for use with Afrikaans-speaking children. This study aimed to determine how the morpho-syntactic abilities of Afrikaans-speaking preschoolers can best be assessed.

The results indicate that of the comprehension tasks, picture selection rendered both the highest number of correct and usable responses, whereas language sample elicitation was the production task rendering the highest number of correct and usable responses. The first recommendation is that these tasks are chosen rather than others when assessing the morphosyntactic abilities of Afrikaans-speaking preschool children. However, since some aspects, such as the comprehension and production of certain types of question forms, are not be assessable using these tasks, tasks yielding a lower number of correct responses and/or a higher number of unusable responses will have to be used, given the lack of alternatives. The generalisability of the results of this study is, however, limited by the small number of participants in each age group. For this reason, further research is needed on children in each age group.

\section{END NOTE}

\footnotetext{
${ }^{1}$ To date, only three diagnostic language tests have been developed for use with Afrikaans-speaking children. The first is the Toets vir Mondelinge Taalproduksie (Test for Oral Language Production) by Vorster (1980). This test is not widely used, amongst other reasons because it has poor test-retest reliability (according to Vorster himself). Also, because of its age, this test is not informed by any developments in the field of syntax in the past 25 years. The second is the Afrikaanse Reseptiewe Woordeskattoets (Afrikaans Receptive Vocabulary Test) by Buitendag (1994). As its name implies, this test evaluates the receptive vocabulary level of Afrikaansspeaking children. The third test is the Afrikaanse Semantiese Taalevalueringsmedium (Afrikaans Semantic Language Evaluation Medium) by Pretorius (1989), which evaluates the receptive and expressive semantic abilities of Afrikaans-speaking children.
} 


\section{REFERENCES}

BORTOLINI, U, MC CASELLI, P DEEVY \& LB LEONARD. 2002. Specific language impairment in Italian: the first steps in search for a clinical marker. International Journal of Language and Communication Disorders, 37(2): 77-94.

BORTOLINI, U, LB LEONARD \& MC CASELLI. 1998. Specific language impairment in Italian and English: Evaluating alternative accounts of grammatical deficits. Language and Cognitive Processes, 13(1):1-20.

BROWN, R. 1973. A first language: The early stages. Cambridge, MA: Harvard University Press.

BUITENDAG, MM. 1994. Afrikaanse Reseptiewe Woordeskattoets. Pretoria: Raad vir Geesteswetenskaplike Navorsing.

CLAHSEN, H. 1988. Normale und gestörte Kindersprache. Linguistische Unterzuchen zum Erwerb von Syntax und Morphologie [Normal and disordered child language. Linguistic examinations on the acquisition of syntax and morphology]. Amsterdam: Benjamins.

CLAHSEN, H. 1989. The grammatical characterization of developmental dysphasia. Linguistics, 27: 897-920.

CLAHSEN, H \& M ROTHWEILER. 1992. Inflectional rules in children's grammars: evidence from German particles. In Booij, G \& J van Marle (eds), Yearbook of Morphology 1992. Dordrect: Kluwer , 1-34.

CRYSTAL, D, P FLETCHER \& M GARMAN. 1976. The grammatical analysis of language disability. London: Edward Arnold.

CRYSTAL, D, P FLETCHER \& M GARMAN. 1989. The grammatical analysis of language disability $\left(2^{\text {nd }}\right.$ ed). London: Edward Arnold.

DALALAKIS, J. 1994. Developmental language impairment in Greek. McGill Working Papers in Linguistics, 10(1/2): 216-227.

DALALAKIS, J. 1997. Developmental language impairment (DLI) and diminutive formation in Greek. Boston University Conference on Language Development Proceedings, 21: 115-123.

DE JONG, J. 2004. Grammatical impairment: An overview and a sketch of Dutch. In Verhoeven L \& H Van Balkom (eds), Classification of developmental language disorders. Theoretical issues and clinical implications. Mahwah: Lawrence Erlbaum, 261-282.

DEMUTH, K \& S SUZMAN. 1997. Language impairment in Zulu. Boston University Conference on Language Development Conference Proceedings, 21: 124-135. 
DE VILLIERS, J. 2005. A touchy subject: why and when do children misinterpret pronouns? Presentation given at University of Cape Town's English Language and Literature Open Seminar Series, 23 February 2005.

FRANKS, SL \& PJ CONNELL. 1996. Knowledge of binding in normal and SLI children. Journal of Child Language, 23: 431-464.

FUKUDA, SE \& S FUKUDA. 1994. Developmental language impairment in Japanese: a linguistic investigation. McGill Working Papers in Linguistics, 10(1/2): 150-177.

GOPNIK, M. 1990. Feature blindness: A case study. Language Acquisition, 1(2): 139-164.

GUALMINI, A \& S CRAIN. 2002. Why no child or adult must learn De Morgan's laws. Boston University Conference on Language Development Conference Proceedings, 26: 243-254.

GUALMINI, A, S CRAIN \& L MERONI. 2000. Acquisition of Disjunction in Conditional Sentences. Boston University Conference on Language Development Conference Proceedings, 24: 367-378.

HÅKANSSON, G. 1998. Language impairment and the realization of finiteness. Boston University Conference on Language Development Conference Proceedings, 22: 314324.

HÅKANSSON, G. 2001. Tense morphology and verb-second in Swedish L1 children, L2 children and children with SLI. Bilingualism: Language and Cognition, 4: 85-99.

HANSSON K \& LB LEONARD. 2003. The use and productivity of verb morphology in specific language impairment: An examination of Swedish. Linguistics, 41: 351-379.

HANSSON, K \& U NETTELBLADT. 1995. Grammatical characteristics of Swedish children with SLI. Journal of Speech and Hearing Research, 38: 589-598.

HORNSTEIN, N, J NUNES \& KK GROHMANN. 2003. Understanding minimalism: An introduction to minimalist syntax. Chapter 9. Feature interpretability and feature checking. Manuscript.

JAKUBOWICZ, C. 2003. Computational complexity and the acquisition of functional categories by French-speaking children with SLI. Linguistics, 41(2): 175-211.

LEONARD, LB. 1995. Functional categories in the grammars of children with specific language impairment. Journal of Speech and Hearing Research, 38: 1270-1283.

LEONARD, LB, U BORTOLINI, MC CASELLI, KK MCGREGOR \& L SABBADINI. 1992. Morphological deficits in children with specific language impairment: The status of features in the underlying grammar. Language Acquisition, 2(2): 151-179. 
LEONARD, LB, L SABBADINI, V VOLTERRA AND JS LEONARD. 1988. Some influences on the grammar of English- and Italian-speaking children with specific language impairment. Applied Psycholinguistics, 9(1): 39-57.

LEONARD, LB, E-K SALAMEH \& K HANSSON. 2001. Noun phrase morphology in Swedish-speaking children with specific language impairment. Applied Psycholinguistics, 22(4):619-639.

LINDER, K \& J JOHNSTON. 1992. Grammatical morphology in language-impaired children acquiring English or German as their first language: A functional perspective. Applied Psycholinguistics, 13: 115-129.

MARCHMAN VA, C SACCUMAN \& B WULFECK. 2004. Productive use of the English past tense in children with focal brain injury and specific language impairment. Brain and Language, 88: 202-214.

PARADIS J \& M CRAGO. 2000. Tense and temporality: A comparison between children learning a second language and children with SLI. Journal of Speech, Language, and Hearing Research, 43: 834-837.

PRETORIUS, A. 1989. Die Afrikaanse Semantiese Taalevalueringsmedium. Pretoria: Author.

RAVID, D, R LEVIE \& GA BEN-ZVI. 2003. The role of language typology in linguistic development: Implications for the study of language disorders. In Levy Y \& J Schaeffer (eds), Language competence across populations. Toward a definition of specific language impairment. Mahwah: Lawrence Erlbaum Associates, 171-193.

RICE ML. 2003. A unified model of specific and general language delay: Grammatical tense as a clinical marker of unexpected variation. In Levy Y \& J Schaeffer (eds), Language competence across populations. Toward a definition of specific language impairment. Mahwah: Lawrence Erlbaum Associates, 63-95.

ROM, A \& LB LEONARD. 1990. Interpreting deficits in grammatical morphology in specifically language-impaired children: preliminary evidence from Hebrew. Clinical Linguistics and Phonetics, 4(2): 93-105.

ROSE, Y \& P ROYLE. 1999. Uninflected structure in familial language impairment: evidence from French. Folia Phoniatrica et Logopaedica, 51: 70-90.

SEYMOUR, HN, TW ROEPER, J DE VILLIERS \& P DE VILLIERS. 2003. Diagnostic evaluation of language variance (DELV-criterion referenced). San Antonio, TX: Harcourt Assessment, Inc.

SOUTHWOOD, F \& AF RUSSELL. 2004. Comparison of conversation, freeplay, and story generation as methods of language sample elicitation. Journal of Speech, Language, and Hearing Research, 47: 366-376. 
STAVRAKAKI, S. 2001. Comprehension of reversible relative clauses in specifically language impaired and normally developing Greek children. Brain and Language, 77: 419-431.

STAVRAKAKI, S. 2002. A-bar movement constructions in Greek children with SLI: evidence for deficits in the syntactic component of language. In Fava, E (ed.), Clinical linguistics: theory and applications in speech pathology and therapy. Amsterdam \& Philadelphia: John Benjamins. 131-153.

SUZMAN, SM. 2002. Morphological accessibility in Zulu. In Fava, E (ed.), Clinical Linguistics: Theory and applications in speech pathology and therapy. Amsterdam \& Philadelphia: John Benjamins: 154-175.

TANAKA-WELTY, Y., J. WATANABE AND L. MENN. 2002. Language production in Japanese preschoolers with specific language impairment: testing theories. In Fava, E (ed.), Clinical Linguistics: Theory and applications in speech pathology and therapy. Amsterdam \& Philadelphia: John Benjamins: 175-193.

TSIMPLI, IM \& S STAVRAKAKI. 1999. The effects of a morphosyntactic deficit in the determiner system: the case of a Greek SLI child. Lingua, 108:31-85.

ULLMANN M \& M GOPNIK. 1994. The production of inflectional morphology in hereditary specific language impairment. McGill Working Papers in Linguistics, 10(1/2):81-118.

VAN DER LELY, HKJ. 1996. Specifically language impaired and normally developing children: verbal passive vs adjectival passive sentence interpretation. Lingua, 98:243272.

VORSTER, J. 1980. Toets vir mondeling taalproduksie. Pretoria: South African Institute for Psychological and Psychometric Research.

\section{Biographic Note}

Frenette Southwood is a lecturer in the Department of General Linguistics at Stellenbosch University. She has a strong interest in developmental language disorders and second language acquisition. 


\section{APPENDIX A: EXAMPLES OF TEST ITEMS}

\section{COMPREHENSION TASKS}

\section{Number}

Picture selection: Wys vir my die vurke [The participant then had to choose between four pictures: (i) one picture corresponding to the requested word (vurke 'forks'); (ii) one picture corresponding to the requested word without the relevant morpheme (vurk 'fork'); (iii) one semantically related distracter, in its plural form (messe 'knives'); and (iv) one phonetically related distracter (varke 'pigs').]

Judgement: *Een rok, twee roks 'One dress, two dresses'; Een tonke, twee tonkes; *Een hond, baie honte 'One dog, two dogs'

\section{Person and case}

The tasks involved pronoun forms. (Person and case are not overtly indicated on nouns and verbs in Afrikaans, but person and case are indicated on pronouns, in the form of phonetic changes.) The participant was first told which picture of a woman would represent the researcher throughout the task as well as which picture of a child would represent the participant. Even the 3-year-olds understood this explanation.

Picture selection: Wys vir my 'Sy eet roomys' 'Show me 'She is eating ice cream' [The participant then had to choose between four pictures, each of a person or persons eating ice cream: (i) one of a woman and a child (representing the researcher and participant); (ii) one of a man; (iii) one of a woman on her own; and (iv) one of a group of people.]

Judgement: Sy lees 'She is reading'; *Haar lees 'Her is reading'; or *Hulle lees 'They are reading' [when describing a picture of a girl reading a book.]

\section{Genitive case}

These tasks assessed the comprehension and production of se-constructions, where se is one of the Afrikaans possessive forms, equivalent to the English ' $s$. Only genitive case was assessed, as other cases are not indicated by separate morphemes (or by suffixes) in Afrikaans.

Picture selection: Wys vir my die vrou se hoed 'Show me the woman's hat' [The participant then had to choose between three pictures: (i) one of a woman wearing a hat; one of a woman without a hat, (iii) and one of a man's hat (such as a cowboy hat).].

Judgement: Dit is die dogtertjie se handdoek 'This is the girl's towel' or *Dit is die hond been 'This is the dog bone' [while pointing to a picture of a girl's towel and a dog's bone, respectively.]

\section{Tense}

Picture selection: Die posman was hier 'The postman was here' or Die sap val om 'The juice is toppling over' [The participant then had to choose between three pictures: (i) one in which an action is being performed, (ii) one in which the action will still be performed, and (iii) one in which the action has been performed.]

Judgement: Hy het gesit en slaap 'He sat sleeping all day long' or *Hy het vir die bus staan en gewag 'He stood and waited for the bus' [while pointing to appropriate pictures.] 


\section{Question forms}

These tasks were both based on those of the Diagnostic Evaluation of Language Variance (DELV-Criterion Referenced) (Seymour, Roeper, de Villiers \& de Villiers, 2003).

Answering long-distance wh-questions: Wat sê sy doen sy? 'What does she say she is doing?' [while pointing to a picture of a woman lying in bed and talking on her cell phone. In a speech bubble, she is depicted swimming. So she is resting, but she tells her conversation partner that she is swimming.]

Answering blocked-interpretation wh-questions: Wie het die skoen wat deur die venster gegooi is, opgetel? 'Who picked up the shoe that was thrown through the window?' [after being told the following story: Twee broers het met mekaar baklei. Die groot broer het kwaad geword en per ongeluk' 'n skoen deur die ruit gegooi. Die klein boetie het die skoen gaan optel. Hulle ma was baie kwaad. 'Two brothers were fighting. The big brother became angry and accidentally threw a shoe through the window. The little brother went to pick the shoe up. Their mother was very angry'.]

\section{Binding relations}

Picture selection: Die dogtertjie en die hasie gee vir mekaar presente 'The girl and the rabbit are giving gifts to one another' [The participant then had to choose between four pictures: (i) one of a girl and a rabbit giving gifts to one another; (ii) one of more than one girl and more than one rabbit giving gifts to each other; (iii) one of a girl giving a gift to a boy; and (iv) one of a girl with a gift.]

Judgement: *Die kat jaag homself 'The cat is chasing himself' [while pointing to a picture of a cat chasing a mouse.]

\section{Passive constructions}

This is a modified version of the task used by Van der Lely (1996).

Picture selection: Die bus word deur die vragmotor gesleep 'The bus is towed by the truck' [The participant then had to choose between three pictures: (i) one of a bus towing a truck; (ii) one of a truck towing a bus; and (iii) one of a truck towing a bicycle.]

\section{PRODUCTION TASKS}

\section{Number}

Sentence completion: Hier is een blom, maar hier (pointing to the rest of the flowers) is baie ... 'Here is one flower, but here are many ...' or Hier is een fasel, maar hier (pointing to two little figures) is baie ... 'Here is one fasel, but here are many ...'.

\section{Person and case}

As was the case for the comprehension tasks, the production task involved pronoun forms. Because singular and plural forms of the pronouns were assessed, these tasks, in fact, assessed not only person and case, but also number.

Sentence completion: Hy eet ' $n$ appel, maar (pointing to the picture of a group of children who are eating cake) ... 'He is eating an apple, but ...'. 


\section{Genitive case}

Sentence completion: Hier is die blom se blare en hier (pointing to the leaves of the tree) is ... 'Here are the flower's petals and here are ...'.

\section{Tense}

Sentence completion: Hierdie apie dra elke dag 'n pak. Gister, net soos elke ander dag, ... 'This monkey wears a suit every day. Yesterday, just like every other day, ...'.

\section{Question forms}

Again, these tasks were both based on those of the Diagnostic Evaluation of Language Variance (DELV-Criterion Referenced) (Seymour et al., 2003). Following Seymour et al. (2003), there was some humour in the pictures, so that it was not predictable what the hidden part of the picture was.

Asking simple wh-questions: Kyk, hierdie verpleegster voer iemand. Vra vir my die regte vraag en dan sal ek vir jou die antwoord wys 'Look, this nurse is feeding someone. Ask me the right question and then I'll show you the answer.' [while pointing at a picture of a nurse feeding someone who is blocked out of the picture.]

Asking paired wh-questions: Hier is 'n pa en hier is 'n ma. Een van hulle is baie kwaad om een of ander rede. Vra vir my die regte vraag en dan sal ek vir jou die antwoord wys 'Here is a father and here is a mother. For some or other reason, one of them is very angry. Ask me the right question and I'll show you the answer' [while pointing at a picture of a family standing under an umbrella.]

\section{Binding relations}

Sentence completion: Die leeus sê elke apie krap ... 'The lions say each monkey is scratching ...' [while pointing at a picture of two lions saying (in a speech bubble) that two monkeys were each scratching themselves.]

\section{Passive constructions}

Sentence completion: Iemand spat vir iemand hierso nat. Die eend ... 'Here someone is splashing water on someone. The duck ...' [while pointing at a picture of a frog splashing water on a duck.] 


\section{APPENDIX B: EXAMPLES OF UNUSABLE RESPONSES}

\section{COMPREHENSION TASKS}

\section{Number}

Picture selection: The following six test items were unfamiliar to at least 2 of the 8 children (the picture selected in the place of the target appears in parentheses):

enkel 'ankle' (winkel 'shop', voete 'feet');

uitveër 'eraser' (ruitveër 'windscreen wiper', potlood 'pencil');

seël 'stamp' (meel 'flour', Ek weet nie wat dit is nie 'I don't know what it is');

teël 'tile' (tol 'top', plank 'piece of timber', no response);

tjops 'chops' (worsies 'sausages', Tjips? Wat is tjops? 'Chips? What are chops?'); and

ketels 'kettles' (sleutels 'keys').

Words to be used as items were selected carefully, amongst others on the basis of the semantic field to which they belong (Pretorius, 1989, was consulted to ascertain which semantic fields develop early on). The fact that these items were unfamiliar to at least $25 \%$ of the participants was therefore unexpected.

Judgement: Most of the unusable responses entailed word substitutions. For instance, some participants judged *golfe 'waves' and *bese 'cattle' to be incorrect and spontaneously provided what they thought to be the correct word, namely branders 'waves' or see 'sea' and koeie 'cows', respectively. Some correct plural forms, such as lammers 'lambs' and duiwe 'doves', were judged to be incorrect and alternatives were provided (lammetjies 'lambsDIMINUTIVE or skapies 'sheep-DIMINUTIVE-PLURAL', and voëls 'birds', respectively). Three items, namely blaaie 'pages', sleepwaens 'trailers', and brûe 'bridges', elicited one response each in which participants said that they did not know the word. Due to the limited number of depictable Afrikaans words which have an irregular plural form, these items are not easily replaceable.

\section{Person and case}

Picture selection: All responses were usable.

Judgement: Only two responses were unusable. The first was Die hond spring oor hulle, which was a correct description of the picture, but which the participant judged to be incorrect, want 'n hond kan nie spring nie 'because a dog cannot jump'. The second related to a picture of a cupboard with two shelves. On the larger, bottom shelve there was a broom and on the smaller, top shelve some cups. The researcher said Die koppies staan bo dit (pointing to the broom as the dit was said). Two participants judged this correct utterance to be incorrect, both spontaneously providing what they thought to be the correct alternative, namely Die koppies staan op die kassie 'The cups are standing on the cupboard (shelve)' and bo-op die kas 'on top of the cupboard'

\section{Genitive case}

Picture selection: All responses were usable.

Judgement: Two items rendered unusable responses. The first was *hond been 'dog bone', to which one participant gave the target response, namely that it is correct, but then spontaneously offered ronde sirkeltjie 'round circle-DIMINUTIVE' as alternative, making it difficult to interpret the response. The second is die seun vis 'the boy fish' for which two participants spontaneously gave alternatives after judging it to be incorrect: seevis 'sea fish' and Dis 'n meisievis. As ' $n$ vis nie lipstick aanhet nie, is dit ' $n$ meisievis 'It is a girl fish. If a fish is not wearing lipstick, it is a girl fish'. 


\section{Tense}

Picture selection: See text.

Judgement: Social judgements made by participants included the following:

Nee, kan nie heeldag miaau nie 'No, cannot mew all day' to *Gister het die kat heeldag staan en gemiaau 'Yesterday the cat mewed all day long';

Nee, hy mag nie loop en eet nie 'No, he may not eat while he is walking' and Nee, hy gaan verstik 'No, he will choke' to Hy het geloop en eet 'He ate while walking'; and

Nee, hy het gestaan en gedink 'No he stood and thought' to *Die man het loop en gedink 'The man thought while walking'.

\section{Binding relations}

Picture selection: All responses were usable.

Judgement: Social judgements included:

Nee, 'n mens moenie baklei nie 'No, one shouldn't fight' to *Die kinders baklei met hom 'The children are fighting with him'; and

$J a$, as hy dood is, moet hy nog begrawe is 'Yes, if he is dead, he must still be buried is' to *Die seuntjie het haarself in die sand begrawe 'The boy buried herself in the sand'.

\section{Passive constructions}

Picture selection: Only one unusable response occurred, when a participant selected the picture of a car bumping into another car when the researcher said, Die kar word deur die bus gestamp 'The car is bumped into by the bus'.

\section{Question forms}

Question answering: Only one unusable response occurred, when a participant responded with Nou die dag, toe hulle gestap het 'The other day, when they were walking' to the question Wanneer het varkie wat in die modder gerol het, huis toe gegaan? 'When did the piggy that rolled in the mud go home?' after being told the following story:

Hierdie twee varkies het op 'n plaas gewoon. Die vet varkie het een oggend vroeg in die modder gerol. Toe loop hy saam met sy maatjie op die werf rond. En toe jaag 'n hond hulle. Die maer varkie was bang en het dadelik huis toe gehardloop, maar die vet varkie het eers laat in die aand huis toe gegaan 'These two little pigs lived on a farm. Early one morning, the fat piggy rolled in the mud. After that, he walked around on the yard with his friend. And then a dog started chasing them. The skinny piggy was scared and ran home immediately, but the fat piggy only went home late in the evening'. The participant's response does not reveal how he interpreted the question, i.e., whether he interpreted it as 'When did the piggy roll in the mud?' or as 'When did the piggy go home?'.

\section{PRODUCTION TASKS}

\section{Number}

Sentence completion: The following real word items rendered unusable responses (the plural forms used instead of the target form by the participant appear in parentheses):

ghoen '(type of) marble' (albasters 'marbles' instead of ghoens);

hof 'court' (polisiemanne 'police men' and wowwe instead of howe); and

web 'web' (spinnerakke 'spider's webs' and wit 'white' instead of webbe).

Examples of unusable responses to nonsense word items include:

klier instead of knure as plural form for knuur; 
gys instead of gesse for ges;

staafsels instead of sterge for sterg;

wissels instead of wisse for wis;

liviler instead of latoewiere for latoewier;

slowie instead of slofies for slofie; and

golfiers instead of golle for gol.

\section{Person and case}

Sentence completion: Examples of unusable responses include:

langs tannie 'next to auntie' instead of langs jou 'next to you' to Die hond sit langs hom, maar dié hond sit langs ... 'This dog is sitting next to him, but this dog is sitting next to ...';

Ek praat op die telefoon en jy praat op die telefoon. Ek en jy praat met mekaar 'I am talking on the telephone and you are talking on the telephone. You and I are talking to each other' instead of Ons praat op ons telefone 'We are talking on our telephones' to Sy spring tou, maar ... 'She is skipping rope, but ...'; and

Jy en hy eet banana 'You-SINGULAR and he are eating banana' instead of Julle eet piesangs 'You-PLURAL are eating bananas' to Sy eet appels, maar ... 'She is eating apples, but ...'.

\section{Genitive case}

Sentence completion: All responses were usable.

\section{Tense}

Sentence completion: See text.

\section{Binding relations}

Sentence completion: Examples include the following:

hulle sterte 'their tails' instead of hulself 'themselves' to Die hond sê elke kat borsel ... 'The dog says every cat is brushing...'; and

in hulle swembad 'in their swimming pool' instead of homself 'himself' to Elke pa dink die seun was ... 'Every dad thinks the boy washes ...'.

\section{Passive constructions}

Sentence completion: An example of an response in the active voice is hardloop en die seun wil hom vang 'runs and the boy wants to catch him' to the researcher saying Die perd ... 'The horse ...' while showing the participant a picture of a horse being chased by a boy.

\section{Question forms}

Question answering: An example of a guess is Dis 'n muur 'It's a wall' to Kyk, hierdie meisie verf iets. Vra vir my die regte vraag dan wys ek jou die antwoord 'Look, this girl is painting something. Ask me the right question and I'll show you the answer'.

An example of the use of an unexpected question word is Wat doen die mense? 'What are the people doing?' instead of Wanneer gaan hulle met vakansie? 'When are they going on holiday?' to Hierdie mense gaan een of ander tyd met vakansie. Vra vir my die regte vraag dan wys ek jou die antwoord 'These people are going on holiday at some or other time. Ask me the right question and I'll show you the answer'. 